\title{
Archaeological Survey and Testing: Castroville's County Village, Unit One, Medina County, Texas
}

Ralph Snavely

Follow this and additional works at: https://scholarworks.sfasu.edu/ita

Part of the American Material Culture Commons, Archaeological Anthropology Commons, Environmental Studies Commons, Other American Studies Commons, Other Arts and Humanities Commons, Other History of Art, Architecture, and Archaeology Commons, and the United States History Commons

Tell us how this article helped you.

This Article is brought to you for free and open access by the Center for Regional Heritage Research at SFA ScholarWorks. It has been accepted for inclusion in Index of Texas Archaeology: Open Access Gray Literature from the Lone Star State by an authorized editor of SFA ScholarWorks. For more information, please contact cdsscholarworks@sfasu.edu. 
Archaeological Survey and Testing: Castroville's County Village, Unit One, Medina County, Texas

\section{Creative Commons License}

\section{(c) (1) (9)}

This work is licensed under a Creative Commons Attribution-NonCommercial 4.0 International License 


\section{ARCHAEOLOGICAL SURVEY AND TESTING: \\ CASTROVILLE'S COUNTRY VILLAGE, UNIT ONE, MEDINA COUNTY, TEXAS}

\section{Ralph Snavely}

Center for Archaeological Research The University of Texas at San Antonio Archaeological Survey Report, No. 145 
ARCHAEOLOGICAL SURVEY AND TESTING:

CASTROVILLE'S COUNTRY VILLAGE, UNIT ONE,

MEDINA COUNTY, TEXAS

Ralph Snavely

Center for Archaeological Research The University of Texas at San Antonio Archaeological Survey Report, No. 145 


\section{ABSTRACT}

During October 24-26, 1984, the Center for Archaeological Research (CAR), The University of Texas at San Antonio (UTSA), conducted a survey of approximately 30 acres of a housing development site on the northeast edge of Castroville in Medina County, Texas. The survey was required as part of Veterans Administration grant application. One area with in the development zone was found to have a light surface scatter of cultural materials. This 1 ithic scatter was recorded and assigned a permanent state site designation (4l ME 31). Shovel tests throughout the site area failed to produce any subsurface cultural material, and we recommend that no further work is needed. The cultural resource found within the survey area was determined not to be significant, and therefore not eligible for nomination to the National Register of Historic Places. 
TABLE OF CONTENTS

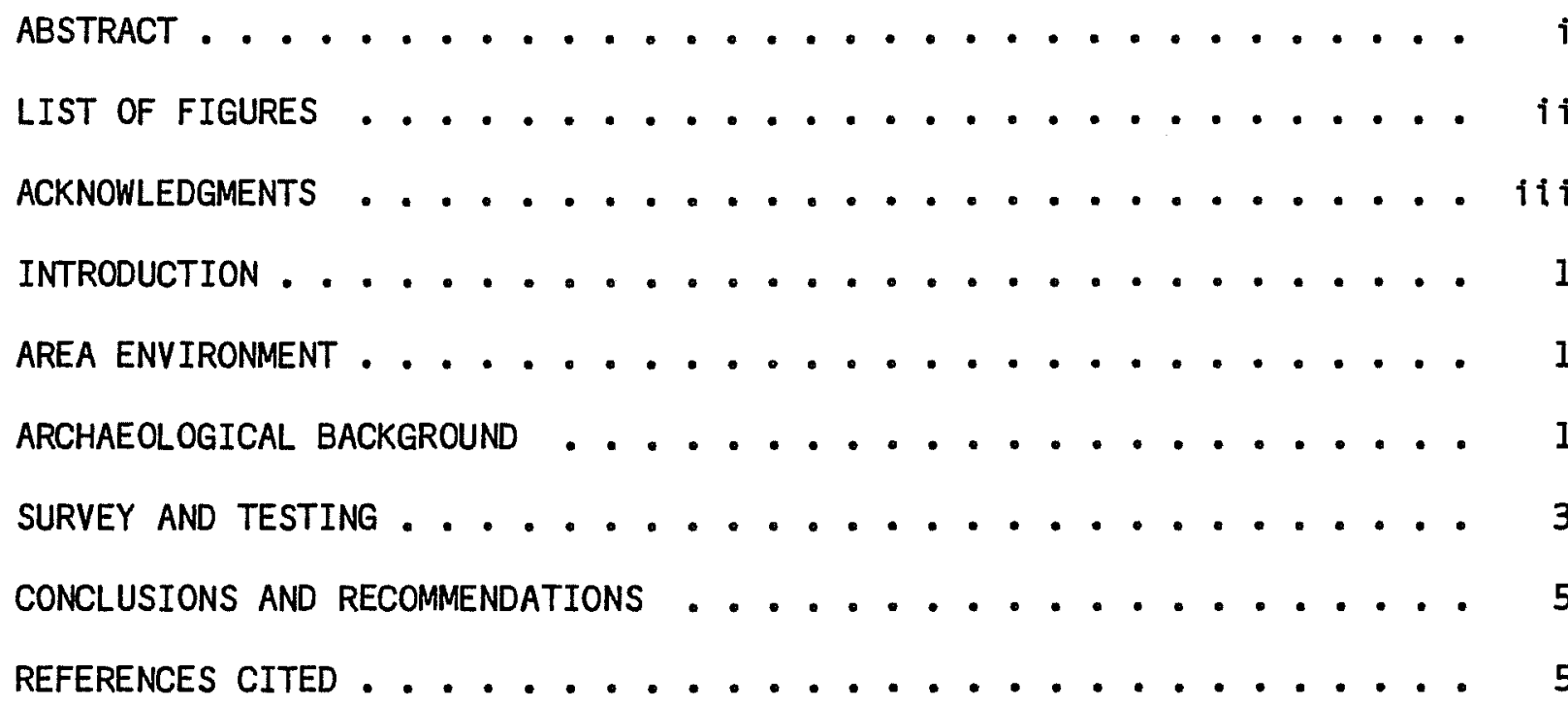

\section{LIST OF FIGURES}

1. Locations of Castrovilie's Country Village Housing Development

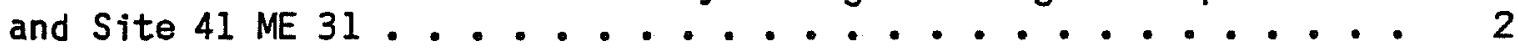

2. Plat of Castroville's Country Village, Unit One and Location of Site 41 ME 31 ..................... 


\section{ACKNOWLEDGMENTS}

I am grateful to a number of peop 1 e who greatly expedited the field work. David Suehs, a local archaeological enthusiast provided information and insight on unrecorded sites along the Medina River. Mrs. Genny Tschirhart, from Genny Tschirhart Realty, was very supportive of the project. The preparation of this report was aided by Ann Young, Sharon Quirk, and Jack Eaton from the Center for Archaeological Research. 


\section{INTRODUCTION}

During October 24-26, 1984, the Center for Archaeological Research (CAR), The University of Texas at San Antonio (UTSA), conducted a pedestrian survey of a 30-acre housing development tract, Unit One of Castroville's Country Village, located one kilometer northeast of the intersection of State Highway 90 and the Medina River. Castroville is in the eastern part of Medina County, Texas (Fig. 1).

The survey was done under contract between the CAR-UTSA and Genny Tschirhart Realty (letter dated October 23, 1984). The survey was requested as part of the requirements for Veterans Administration grant application and is in compliance with the National Historic Preservation Act of 1966, as amended, and Executive Order 11593.

The field work was conducted by Ralph Snavely, CAR staff archaeologist, under the supervision of Thomas R. Hester, CAR Director, and Jack D. Eaton, Associate Director.

The main objectives of the survey were: (1) to determine by surface examination and shovel tests if archaeological cultural resources are present with in the study area; and (2) to form recommendations for any further work needed in order to determine site(s) eligibility for nomination to the National Register of Historic Places.

\section{AREA ENVIRONMENT}

Drainage systems associated with the survey area are the Medina River to the west and Flat Creek to the east. Less than five feet of topographic relief occurs within the study area; this may be the result of clearing, plowing, and other 1 and modifying agricultural practices.

The entire survey area has recently been under cultivation. The flora of the immediate study area is not necessarily indicative of the naturally occurring flora. In its natural state, the study area would fit into the Tamaul ipan Biotic Province, where the predominant vegetation is thorny brush. This thorny brush vegetation consists of mesquite, acacia, mimosa, whitebrush, and prickly pear (Blair 1950). Dense vegetation including cypress, oak, and native pecan trees occur most often in the riparian zones. Along the Medina River bank, one kilometer west of the survey area, an excellent example of a riparian environment exists.

Fauna present in the survey area is typical of the South Texas Coastal Plains region. A complete 1 isting of fauna and flora relevant to Medina County can be found by consulting Dittmar et a1. (1977).

\section{ARCHAEOLOGICAL BACKGROUND}

Thirty-one archaeological sites have been recorded in Medina County, but none of these were located with in the survey area. The scarcity of recorded sites 
This page has been

redacted because it

contains restricted

information. 
in this area may be due to agriculturaliy reiated 1 and modifications obscuring or destroying intact cultural remains.

Scorpian Cave (41 ME 7), approximately $15 \mathrm{miles}$ north of the survey area, has been extensively investigated. Cultural remains indicated an occupational span from the Middle Archaic to the Late Prehistoric period (Highley et al. 1980; Hightey and Graves 1978).

Patterson (1973) studied the blade technology at quarry site 41 ME 3 and recorded nine sites (4I ME 9, 41 ME 10, 41 ME 11, 41 ME 12, 41 ME 13, $41 \mathrm{ME}$ 14, $41 \mathrm{ME} \mathrm{15,} 41 \mathrm{ME}$ 16, $41 \mathrm{ME}$ 17) in north-central Medina County (Patterson 1975). In 1976, the CAR investigated four sites (4I ME 18, 41 ME 19, 41 ME 20, 41 ME 21) on the Medina River near Natalia in southeast Medina County (Hester and Kelly 1976). In 1975, the Texas Historical Commission conducted historic site excavations at the Landmark Inn (41 ME 6) in Castroville (Texas Archeological Research Laboratory [TARL] files).

\section{SURVEY AND TESTING}

The field survey consisted of a series of transects across the entire area of study. The survey area is divided into lots and covers approximately 30 acres (Fig. 2). Each lot was actually transected several times. Observations were recorded on the occurrence, density, and location of prehistoric remains. A USGS topographic map (La Coste quadrant) was consulted to establish the general outlay of the terrain.

Only diagnostic or otherwise significant artifacts were collected for analysis. The collection was necessary because the area is currently under development. The locations of prehistoric remains, mostly 1 ithic debitage, were plotted on a map of the development area.

The study area 1 imits were clearly defined by the roads and other bulldozed 1 and cuts appearing on the survey area map provided by the 7 and developers. The existing profiles of exposed utility trenches and road cuts were inspected for the occurrence of subsurface cultural remains. In addition, shovel tests were made in the area suspected of containing subsurface cultural deposits.

After the entire study area had been surveyed, one area was suspected of being a prehistoric site. Lots 8,9 , and 10 of Block 6 (Fig. 2) located in the northeast corner of the survey area were found to have prehistoric 7 ith ic debris scattered on the ground surface. Further inspection of the area resulted in the collection of one Montell dart point and one core. The dart point is dated to the Late Archaic time period (from the late centuries B.C. to the early centuries A.D.) (Hester 1980). The core is a good quality chert cobble, commonly found in Uvalde Gravels. A natural deposit of these chert bearing gravels occurs in the northeast corner of the survey area.

The surface 1 ithic scatter consists of mostly primary flakes with a few secondary flakes present. This thin lithic scatter may represent a prehistoric chert acquisition area, as raw Uvalde Gravels are available at the site. 
This page has been

redacted because it

contains restricted

information. 
A series of nine shovel tests was excavated randomly across the three 1 ot areas. Each test was approximately $25 \mathrm{~cm}^{2}$ and ranged in depth from 18 to $30 \mathrm{~cm}$. The soil from each shovel test was passed through a 1/4-inch screen. No cultural materials were recovered from these shovel tests.

This site was recorded, and a permanent state archaeological site designation has been assigned (41 ME 31) by the Texas Archeological Research Laboratory (TARL) in Austin. Field notes and the two collected artifacts are curated at the CAR-UTSA.

\section{CONCLUSIONS AND RECOMMENDATIONS}

During the survey, al1 of Unit One in Castroville Country Village development was carefully examined. One location with small amounts of cultural materials on the ground surface was recorded as site 41 ME 31 . A series of shovel tests falled to produce any subsurface cultural material. Therefore, no further work is recommended at site 41 ME 31. However, should development of the 1 and north or east of this site take place, further testing should be required in those areas.

\section{REFERENCES CITED}

Blair, W. F.

1950 The Biotic Provinces of Texas. The Texas Journal of Science I(2):93-116.

Dittmar, G. W., M. L. Deike, and D. E. Richmond

1977 Soil Survey of Medina County Texas. U. S. Department of Agriculture, Soil Conservation Service.

Hester, T. R.

1980 Digging Into South Texas Prehistory. Corona Publishing Company, San Antonio.

Hester, T. R. and T. C. Kelly

1976 Archaeological Investigations at Sites Near Natalia, Medina County, Texas. Center for Archaeological Research, The University of Texas at San Antonio, Archaeological Survey Report 20.

Hightey, L. and C. Graves

1978 Excavations at Scorpion Cave. La Tierra 5(2):10-19. 
Highley, L., C. Graves, C. Land, and G. Judson

1980 Archeological Investigations at Scorpion Cave (4l ME 7) Medina County, Texas. Bulletin of the Texas Archeological Society 49 : 139-198.

Patterson L. W.

1973 Some Lithic Blade Technology in Texas. Bulletin of the Texas Archeological Society $44: 89-112$.

1975 A Quarry Site in Medina County, Texas. La Tierra 2(1):19-23. 